\title{
PREVALENSI EKTOPARASIT PADA UDANG VANAME (Litopenaeus vannamei) DENGAN PADAT TEBAR YANG BERBEDA DI TEMPAT PENGGELONDONGAN DI KABUPATEN GRESIK
}

\section{Prevalence of Ectoparasites on White Shrimp (Litopenaeus vannamei) with Different Stocking Density in Larva Rearing Ponds in Gresik}

\author{
Gunanti Mahasri $^{1}$, Ardilas Heryamin ${ }^{2 *}$ and Kismiyati ${ }^{1}$. \\ ${ }^{1}$ Departemen Manajemen Kesehatan Ikan dan Budidaya Perairan, Fakultas Perikanan dan Kelautan, Universitas \\ Airlangga, Surabaya \\ ${ }^{2}$ Program Studi Budidaya Perairan, Fakultas Perikanan dan Kelautan, Universitas Airlangga, Surabaya \\ *ardilas-h-11@fpk.unair.ac.id
}

\begin{abstract}
Abstrak
Gelondongan udang vaname adalah benih udang vaname yang didapatkan dari suatu hatchery yang memiliki stadia $\mathrm{PL}_{12}-\mathrm{PL}_{15}$ dan dipelihara oleh pembudidaya selama 5-7 hari sehingga umur gelondongan udang vaname berkisar $\mathrm{PL}_{20}-\mathrm{PL}_{22}$. Salah satu faktor yang mempengaruhi tingkat keberhasilan penggelondongan udang vaname adalah padat tebar. Padat tebar yang tinggi akan meningkatkan kandungan bahan organik akibat penumpukan sisa pakan dan sisa metabolisme sehingga udang akan stres dan mudah terinfestasi ektoparasit.

Penelitian ini bertujuan untuk Mengetahui prevalensi ektoparasit pada udang vaname dan mengetahui hubungan korelasi antara prevalensi ektoparasit pada udang vaname dengan padat tebar yang berbeda di tempat penggelondongan di Kabupaten Gresik. Metode yang digunakan dalam penelitian ini adalah metode survey melalui pengambilan sampel. Tempat pengambilan sampel ditentukan dengan kriteria tertentu (purposive sampling) yaitu sentra yang terbesar pada setiap wilayahnya dan memiliki petakan paling banyak.

Parameter utama yang diamati dalam penelitian ini adalah padat tebar dan prevalensi ektoparasit. Parameter pendukung dalam penelitian ini adalah kualitas air pada tambak penggelondongan udang vaname meliputi suhu, kecerahan, $\mathrm{pH}$, oksigen terlarut, salinitas, amonia, nitrit dan nitrat.

Hasil penelitian didapatkan tiga jenis ektoparasit yang menginfestasi gelondongan udang vaname yaitu Zoothamnium, Vorticella dan Epistylis. Prevalensi ektoparasit pada udang vaname (Litopenaeus vannamei) dengan padat tebar yang berbeda di tempat penggelondongan di Kabupaten Gresik adalah sebesar 80,74\%, artinya secara keseluruhan 80,74\% gelondongan udang vaname di Kabupaten Gresik positif terinfestasi ektoparasit. Terdapat hubungan yang sangat erat antara prevalensi ektoparasit pada udang vaname dengan padat tebar yang berbeda di tempat penggelondongan sehingga semakin tinggi padat tebar maka semakin tinggi tingkat prevalensi ektoparasit pada gelondongan udang vaname (Litopenaeus vannamei).
\end{abstract}

Kata kunci: Prevalensi, Ektoparasit, Udang Vaname, Padat Tebar yang Berbeda, Penggelondongan

Abstract

Larva vaname shrimp is obtained from a hatchery who have stadia $\mathrm{PL}_{12}-\mathrm{PL}_{15}$ and maintained by farmers for 5-7 days so that the life of larva vaname shrimp range $\mathrm{PL}_{20}-\mathrm{PL}_{22}$. One of the factors that affect the success rate larva rearing vaname shrimp is stocking density. High stocking density will increase the organic matter content due to accumulation of food remains and the rest of the metabolism so that shrimp will be stress and easily infested ectoparasites.

This study aims to knowing the prevalence of ectoparasites on vaname shrimp and determine the correlation between the prevalence of ectoparasites on vaname shrimp with different stocking density in larva rearing ponds in Gresik. The method used in this research is survey method that through sampling. The sampling locations are determined by certain criteria (purposive sampling) which is the largest center in each region and has pond most.

The research found three types of ectoparasites that infest larva vaname shrimp namely Zoothamnium, Vorticella and Epistylis. The prevalence of ectoparasites on vaname shrimp (Litopenaeus vannamei) with different stocking density in larva rearing ponds in Gresik is equal to $80.74 \%$, meaning that overall $80.74 \%$ of larva vaname shrimp in Gresik positively infested ectoparasites. There is a strong correlation between the prevalence of ectoparasites on larva vaname shrimp with different stocking density in larva rearing ponds so that the higher stocking density, the highers level of prevalence of ectoparasites on larva vaname shrimp (Litopenaeus vannamei). 
Keywords: Prevalence, Ectoparasites, Vaname Shrimp, Different Stocking Density, Larva Rearing

\section{PENDAHULUAN}

Produksi udang vaname pada tahun 2013 mencapai 390.278 ton dan pada tahun 2014 mencapai 411.729 ton, dengan capaian produksi yang semakin meningkat produksi total udang pada tahun 2015 ditargetkan sebesar 785.900 ton dan diharapkan Indonesia kedepan akan menjadi negara produsen udang yang terbesar di Asia bahkan dunia (Kementerian Kelautan dan Perikanan, 2015).

Keberadaan udang vaname di indonesia khususnya jawa timur sudah bukan hal asing lagi bagi petambak, dimana udang introduksi tersebut telah menarik perhatian masyarakat pembudidaya karena kelebihannya (Subyakto dkk., 2009). Udang vaname memiliki kelebihan tahan terhadap lingkungan yang kurang baik terutama pada kandungan oksigen terlarut $\leq 3 \mathrm{ppm}$, nafsu makan yang tinggi dan tahan terhadap serangan penyakit (Adiwijaya dkk., 2008).

Salah satu faktor yang mempengaruhi tingkat keberhasilan penggelondongan udang vaname adalah padat tebar. Selain itu, dapat juga dipengaruhi manajemen pakan dan kualitas air tambak sehingga serangan penyakit tidak dapat dihindarkan dan mengakibatkan kegagalan dalam penggelondongan udang vaname (Adiwijaya dkk., 2001).

Kasus infestasi protozoa perlu mendapatkan perhatian yang serius karena infestasi protozoa pada udang dapat menyebabkan udang kesulitan untuk bernafas, bergerak dan mencari makan. Disamping itu udang juga sulit berganti kulit (moulting), pertumbuhan lambat dan dapat menyebabkan kematian (Mahasri, 2007). Selanjutnya diketahui bahwa beberapa ektoparasit dari kelas protozoa yang sering menginfestasi udang adalah Zoothamnium, Vorticella dan Epistylis.

\section{METODOLOGI}

Waktu dan Tempat
Penelitian ini dilaksanakan di tambak penggelondongan wilayah Gresik meliputi Kecamatan Duduk Sampeyan, Manyar dan Ujung Pangkah sebagai tempat pengambilan sampel, pengujian air sampel di Balai Besar Teknik Kesehatan Lingkungan dan Pengendalian Penyakit (BBTKLP) Surabaya serta pemeriksaan dan pewarnaan ektoparasit dilakukan di Laboratorium Kering Fakultas Perikanan dan Kelautan Universitas Airlangga pada bulan April - Mei 2015.

\section{Materi Penelitian}

Peralatan Penelitian

Peralatan yang digunakan dalam penelitian ini meliputi akuarium, aerasi, botol sampel, termometer, sechi disk, kertas $\mathrm{pH}$, test kit, refraktometer, mikroskop, pinset, object glass, cover glass, pipet tetes, seser, baki dan tisu.

\section{Bahan Penelitian}

Bahan penelitian yang digunakan meliputi sampel gelondongan udang vaname PL-18-PL-25 dan sampel air tambak penggelondongan untuk pengukuran kualitas air yang didapat dari tiga tambak penggelondongan di Kabupaten Gresik meliputi Kecamatan Manyar, Ujung Pangkah dan Duduk Sampeyan. Bahan yang dibutuhkan untuk pewarnaan protozoa dan permanent mounting yaitu Giemsa 10\% dan entellan.

\section{Metode Penelitian}

Metode yang digunakan dalam penelitian ini adalah metode survey melalui pengambilan sampel. Metode survey yaitu mengumpulkan informasi yang berhubungan dengan prevalensi, distribusi dan hubungan antar variabel dalam suatu populasi (Nursalam, 2008). Sangadji dan Sopiah (2010) menjelaskan bahwa lokasi pengambilan sampel ditentukan dengan kriteria tertentu (purposive sampling) yaitu sentra yang terbesar pada setiap wilayah- 
nya dan memiliki petakan paling banyak.

\section{Prosedur Kerja \\ Persiapan alat dan bahan}

Persiapan yang dilakukan adalah mempersiapkan akuarium untuk penampungan gelondongan udang vaname yang diisi dengan air payau serta aerasi sebelum pengambilan sampel kemudian dilakukan pencucian alat yang akan digunakan untuk memeriksa ektoparasit pada gelondongan udang vaname.

\section{Pengambilan sampel}

Pengambilan sampel dilakukan di tempat penggelondongan Kabupaten Gresik yang meliputi Kecamatan Manyar mewakili Gresik Timur, Ujung Pangkah mewakili Gresik Utara dan Duduk Sampeyan mewakili Gresik Selatan, sedangkan pada Gresik Barat tidak diambil sampel dikarenakan tidak adanya kegiatan penggelondongan di daerah tersebut. Masing-masing lokasi tersebut diambil 30 ekor tiap tambak sebanyak 3 tambak setiap kecamatan, sehingga total sampel sebanyak 270 ekor. Ketiga tambak pada setiap kecamatan yang dipilih untuk pengambilan sampel berdasarkan sentra yang terbesar pada wilayah tersebut dan dipilih dengan masing-masing tambak yang memiliki padat tebar gelondongan udang vaname yang berbeda agar dapat mewakili setiap kecamatan.

Sampel yang diambil adalah PL18-PL-25. Banyaknya jumlah sampel ini mengacu pada Cameron (2002) yang menyatakan bahwa jumlah sampel yang digunakan untuk penelitian survey yaitu 27-30 sampel apabila jumlah populasi 100 hingga 1000 ekor, selanjutnya sampel dimasukkan dalam plastik yang diberi oksigen. Sampel air tambak juga diambil pada masing-masing petak tambak penggelondongan udang vaname. Pengambilan sampel dilakukan sebanyak dua kali dalam satu bulan masing-masing sebanyak 15 ekor agar mendapatkan data yang bervariasi. Gelondongan udang vaname diambil pada saat panen pada pagi hari agar udang tidak mudah stress dalam proses trans- portasi dari Gresik ke Surabaya dan sudah terjadwal waktu pengambilannya.

\section{Pemeriksaan sampel dan perhitungan prevalensi ektoparasit yang menginfes- tasi gelondongan udang vaname}

Sampel gelondongan udang vaname dimasukkan ke dalam akuarium sebagai tempat sementara, kemudian gelondongan udang vaname yang diperiksa di letakkan pada object glass lalu diamati menggunakan mikroskop dengan perbesaran 100x dan 400x. Pemeriksaan ektoparasit dilakukan pada gelondongan udang vaname yang masih hidup, bagian yang diperiksa meliputi seluruh permukaan tubuh, insang, kaki, ekor, mata dan karapas (Johnson, 1978). Kemudian dihitung prevalensinya.

\section{Pewarnaan Ektoparasit}

Setelah mendapatkan ektoparasit protozoa selanjutnya dilakukan pewarnaan yang mengacu pada Hadiroseyani dkk. (2006) yaitu preparat yang diperiksa dikeringkan kemudian difiksasi menggunakan metanol selama 5 menit. Setelah itu diwarnai dengan Giemsa 10\% selama 15-20 menit. kemudian dibilas dengan air bersih dan dikeringkan.

\section{Identifikasi Ektoparasit}

Ektoparasit yang ditemukan diidentifikasi berdasarkan ciri-ciri khusus yang ditemukan. Identifikasi Zoothamnium, Vorticella dan Epistylis berdasarkan Wellborn and Rogers (1966) dan Kabata (1985).

\section{Pengukuran kualitas air}

Pengukuran kualitas air dilakukan bersamaan dengan pengambilan sampel gelondongan udang vaname pada masingmasing tambak penggelondongan secara langsung dan pengujian di Balai Besar Teknik Kesehatan Lingkungan dan Pengendalian Penyakit (BBTKLP) Surabaya. Parameter kualitas air yang diukur adalah suhu, kecerahan, $\mathrm{pH}$, amonia, salinitas, oksigen terlarut, nitrit dan nitrat. Pengukuran 
kualitas air dilakukan dua kali pengulangan pada pukul 06.00 dan pukul 12.00 karena suhu pada pagi hari lebih rendah daripada siang hari sehingga tinggi rendahnya kandungan oksigen terlarut tersebut juga berbeda. Pengukuran suhu dilakukan dengan termometer, kecerahan dengan secchi disc, $\mathrm{pH}$ dengan kertas $\mathrm{pH}$ dan salinitas dengan refraktometer. Sedangkan pengukuran amonia, nitrit, nitrat dan oksigen terlarut dengan test kit.

\section{Parameter Penelitian}

Parameter utama yang diamati dalam penelitian ini adalah padat tebar dan prevalensi ektoparasit yang menginfestasi udang vaname dengan padat tebar yang berbeda di tempat penggelondongan.

Parameter pendukung dalam penelitian ini adalah kualitas air pada tambak penggelondongan udang vaname meliputi suhu, kecerahan, $\mathrm{pH}$, oksigen terlarut, Salinitas, amonia, nitrit dan nitrat diukur selama penelitian.

\section{Analisis Data}

Data identifikasi ektoparasit disajikan dalam bentuk gambar, sedangkan data prevalensi disajikan dalam bentuk tabel. Untuk mengetahui korelasi antara padat tebar dan prevalensi serta seberapa kuat hubungannya digunakan analisis korelasiregresi (Steel dan Torrie, 1989).

\section{HASIL DAN PEMBAHASAN Hasil}

Hasil penelitian yang dilakukan terhadap 270 sampel udang vaname di tempat penggelondongan di Kabupaten Gresik ditemukan adanya ektoparasit yaitu Zoothamnium, Vorticella dan Epistylis. Hasil identifikasi ektoparasit yang tersebar di Kabupaten Gresik dapat dilihat pada Tabel 1.

Tabel 1. Hasil Identifikasi Ektoparasit

\begin{tabular}{ccc}
\hline Kecamatan & $\begin{array}{c}\text { Padat } \\
\text { tebar } \\
\text { (ekor/liter) }\end{array}$ & $\begin{array}{c}\text { Ektoparasit } \\
\text { yang } \\
\text { ditemukan }\end{array}$ \\
\hline
\end{tabular}

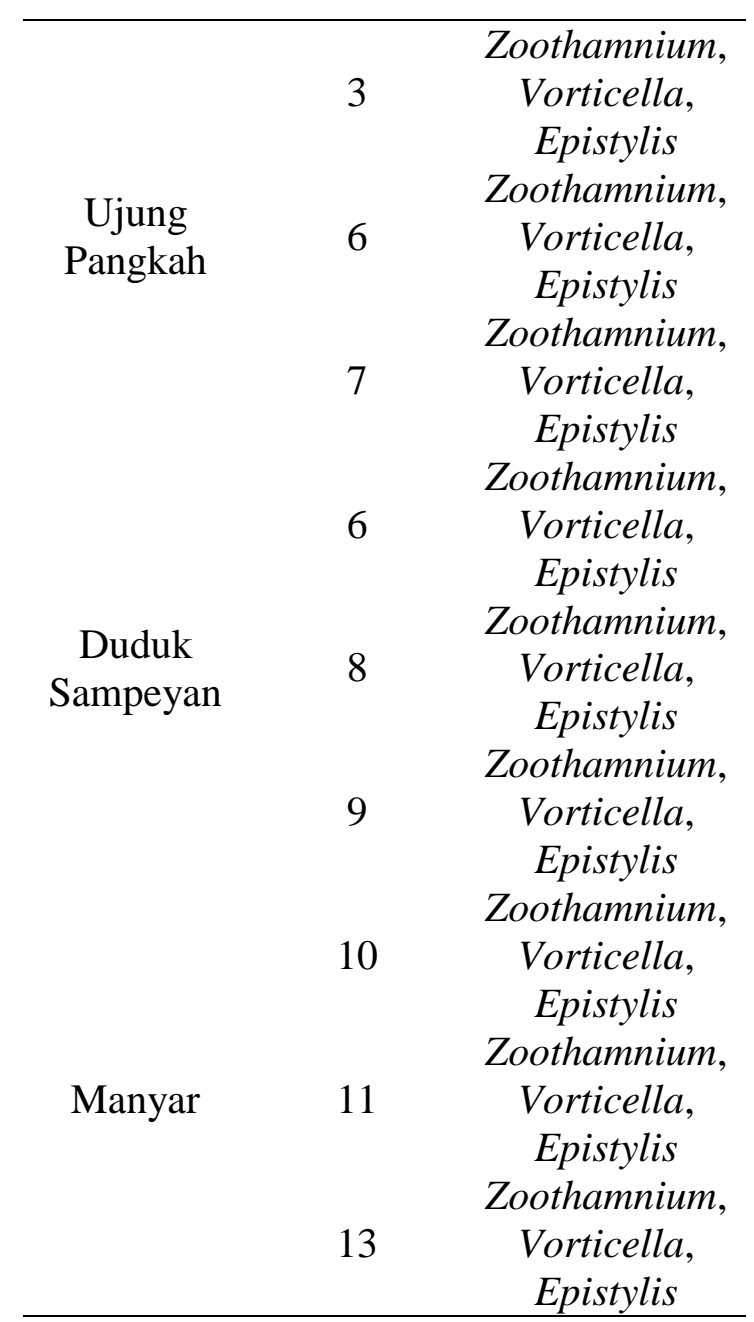

Tingkat prevalensi ektoparasit pada gelondongan udang vaname untuk setiap kali pengambilan sampel pada tempat penggelondongan dengan padat tebar yang berbeda di Kabupaten Gresik menunjukkan hasil yang berbeda. Dari 270 sampel gelondongan udang vaname yang diperoleh dari tempat penggelondongan dengan padat tebar yang berbeda di Kabupaten Gresik diketahui 218 gelondongan positif terinfestasi ektoparasit dengan nilai prevalensi keseluruhan sebesar $80,74 \%$. Hasil pemeriksaan diperoleh data prevalensi yang ditunjukkan pada Tabel 2 .

Hubungan antara padat tebar dengan tingkat prevalensi ektoparasit pada gelondongan udang vaname yaitu terdapat korelasi antara padat tebar dengan tingkat prevalensi ektoparasit pada gelondongan udang vaname. Berdasarkan analisis statistik korelasi dan regresi linier didapatkan nilai $\mathrm{R}=0,876$ dan $\mathrm{r}^{2}=0,767$, dengan 
persamaan regresi $\mathrm{y}=0,448+0,044 \mathrm{x}$, dimana y adalah persentase tingkat prevalensi dan $\mathrm{x}$ adalah persentase padat tebar. Hal ini menunjukkan bahwa adanya korelasi yang sangat erat $(\mathrm{R}=0,876$ dan $\left.\mathrm{r}^{2}=0,767\right)$ antara padat tebar dengan tingkat prevalensi ektoparasit pada gelondongan udang vaname. Tingkat prevalensi yang tertinggi juga terjadi pada tambak dengan padat tebar yang tinggi. Tingkat prevalensi ini menurun pada tambak dengan padat tebar yang lebih rendah.

Tabel 2. Prevalensi Ektoparasit

\begin{tabular}{ccccc}
\hline \multirow{2}{*}{ Kecamatan } & $\begin{array}{c}\text { Padat tebar } \\
\text { (ekor/liter) }\end{array}$ & $\begin{array}{c}\text { Jumlah } \\
\text { Sampel } \\
\text { (ekor) }\end{array}$ & $\begin{array}{c}\text { Jumlah } \\
\text { udang } \\
\text { terinfestasi } \\
\text { ektoparasit }\end{array}$ & Prevalensi (\%) \\
\hline \multirow{2}{*}{ Ujung Pangkah } & 3 & 30 & 17 & 56,66 \\
& 6 & 30 & 19 & 63,33 \\
Duduk Sampeyan & 7 & 30 & 22 & 73,33 \\
& 6 & 30 & 24 & 80 \\
Manyar & 9 & 30 & 25 & 83,33 \\
& 10 & 30 & 28 & 93,33 \\
& 11 & 30 & 23 & 76,66 \\
& 13 & 30 & 30 & 100 \\
& Total & 270 & 30 & 100 \\
\hline
\end{tabular}

\section{Pembahasan}

Nilai prevalensi pada setiap pengambilan sampel yang diperoleh dari tambak penggelondongan di Kabupaten Gresik memiliki nilai yang berbeda. Prevalensi pada tambak dengan padat tebar 3 ekor/liter sebesar $56,66 \%$, pada tambak dengan padat tebar 6 ekor/liter sebesar 63,33\%, pada tambak dengan padat tebar 7 ekor/liter sebesar $73,33 \%$, pada tambak dengan padat tebar 6 ekor/liter sebesar $80 \%$, pada tambak dengan padat tebar 8 ekor/liter sebesar $3,33 \%$, pada tambak dengan padat tebar 9 ekor/liter sebesar 93,33\%, pada tambak dengan padat tebar 10 ekor/liter sebesar $76,66 \%$, pada tambak dengan padat tebar 11 ekor/liter sebesar $100 \%$ dan tambak dengan padat tebar 13 ekor/liter sebesar $100 \%$. Perbedaan tingkat prevalensi pada setiap pengambilan sampel gelondongan udang vaname diduga juga dipengaruhi oleh faktor lain yaitu kualitas air.

Padat tebar yang tinggi menyebabkan persaingan ruang dalam tambak sehingga memudahkan udang yang terinfestasi protozoa kontak langsung dengan gelondongan udang vaname yang lain.
Umumnya cara penularan protozoa adalah adanya kontak langsung antara gelondongan udang vaname dan protozoa (Mahasri, 1996). Tingkat prevalensi tersebut diduga terkait dengan padat tebar dan kualitas air yang kurang baik. Menurut Anonimus (1993) Pada padat tebar yang terlalu tinggi juga akan menyebabkan gelondongan udang vaname sulit bergerak, sehingga gelondongan tersebut mudah stres dan mudah terserang penyakit, walaupun dalam keadaan normal. Adiwijaya dkk. (2001) menambahkan selain padat tebar, faktor lain yang mempengaruhi kegiatan penggelondongan udang vaname adalah kualitas air.

Terdapat korelasi yang sangat erat antara tingkat prevalensi ektoparasit dengan padat tebar yaitu semakin tinggi padat tebar maka semakin tinggi tingkat prevalensi ektoparasit yang menginfestasi gelondongan udang vaname. Dari hasil penelitian menunjukkan bahwa tambak dengan padat tebar yang tinggi menunjukkan adanya infestasi ektoparasit yang tertinggi. Pada padat tebar yang tinggi yang menunjukkan hasil infestasi tertinggi pada 
pemeliharaan gelondongan udang vaname menyebabkan meningkatnya bahan organik dalam perairan yang berasal dari sisa metabolisme, apabila bahan organik ini tidak dapat terurai menjadi bahan anorganik oleh mikroorganisme maka akan menyebabkan munculnya amonia yang dapat mengganggu pertumbuhan udang, hal ini didukung oleh pendapat Mahasri (1996) yang mengatakan bahwa pada padat tebar yang tinggi akan meningkatkan kandungan bahan organik akibat penumpukan sisa pakan. Apabila proses perombakan bahan organik terganggu maka akan terjadi pembusukan sehingga mengakibatkan penurunan $\mathrm{pH}$ dan oksigen terlarut. Hal ini dapat menyebabkan udang stres. Akibatnya kontak langsung antara udang dan parasit cukup tinggi sehingga parasit dengan mudah menginfestasi gelondongan udang vaname serta penularan infestasi parasit cukup cepat dan serangan penyakit tidak dapat dihindarkan. Kelangsungan hidup parasit akan tumbuh dengan baik pada kandungan oksigen yang rendah yaitu dibawah 3 ppm sehingga padat tebar yang tinggi dapat meningkatkan infestasi parasit.

\section{KESIMPULAN DAN SARAN Kesimpulan}

Prevalensi ektoparasit pada udang vaname (Litopenaeus vannamei) dengan padat tebar yang berbeda di tempat penggelondongan di Kabupaten Gresik adalah sebesar $80,74 \%$, artinya biasanya protozoa menginfestasi gelondongan udang vaname di Kabupaten Gresik. Terdapat korelasi yang sangat erat antara prevalensi ektoparasit pada udang vaname dengan padat tebar yang berbeda di tempat penggelondongan dengan $R=0,876$ dan $r^{2}$ $=0,767$ menunjukkan bahwa padat tebar mempengaruhi prevalensi sebesar 76,7\% sedangkan 23,3\% dipengaruhi oleh faktor lainnya. Hal ini menunjukkan bahwa semakin tinggi padat tebar maka semakin tinggi tingkat prevalensi ektoparasit pada gelondongan udang vaname (Litopenaeus vannamei).

\section{Saran}

Dengan ditemukannya ektoparasit pada gelondongan udang vaname di Kabupaten Gresik dengan tingkat prevalensi yang cukup tinggi, maka diperlukan monitoring terhadap kegiatan penggelondongan udang vaname di Kabupaten Gresik dan perlu adanya penelitian lebih lanjut untuk pencegahan penyebaran ektoparasit sebagai upaya pengembangan usaha budidaya penggelondongan udang vaname.

\section{DAFTAR PUSTAKA}

Adiwidjaya, D., Coco dan Supito. 2001. Teknik Operasional Budidaya Udang Ramah Lingkungan. Balai Besar Pengembangan Air Payau. Direktorat Jenderal Perikanan Budidaya. Departemen Kelautan dan Perikanan. Jepara. 29 hal.

Adiwidjaya, D., Supito dan I. Sumantri. 2008. Penerapan Teknologi Budidaya Udang Vaname L. vannamei Semi-Intensif Pada Lokasi Tambak Salinitas Tinggi. Media Budidaya Air Payau Perekayasaan, 5(7): 119.

Anonimus. 1993. Asian Shrimp News. New Impeteus for Shrimp Farming in India. Asian Shrimp Culture Counsil Published. The 2-nd Quarter (14): 1-5.

Cameron, A. 2002. Survey Toolbox for Aquatic Animal Diseases. A Practical Manual and Software Package. ACIAR Monograph No. 94, $375 \mathrm{p}$.

Direktorat Jenderal Perikanan Budidaya. 2015. KKP Dorong Produktivitas Tambak Udang Dipasena. www.djbp.kkp.go.id. 06/03/15. 2 hal.

Hadiroseyani, Y., P. Hariyadi dan S. Nuryati. 2006. Inventarisasi Parasit Lele Dumbo Clarias sp. di Daerah Bogor. Jurnal Akuakultur Indonesia, 5(2): 167-177.

Johnson, S. K. 1978. Handbook of Shrimp Disease. Teseay A dan M University. Sea Grant Publ. No. 603. 49 p. 
Kabata, Z. 1985. Parasite and Diseases of Fish Cultured in the Tropics. Taylor and Francis. London. 263 p.

Mahasri, G. 1996. Pengaruh Manipulasi Tingkat Aerasi dan Padat Tebar terhadap Infestasi Parasit Udang Windu (Penaeus monodon Fab). Tesis. Program Pascasarjana Institut Pertanian Bogor. 65 hal.

Mahasri, G. 2007. Kemampuan Ikan Bandeng Sebagai Filter Biologis dalam Menekan Munculnya Ciliata Patogen pada Budidaya Udang Windu (Penaeus monodon fab) di Tambak. Jurnal Ilmu Kelautan, 10(4): 1-10.

Nursalam. 2008. Konsep dan Penerapan Metodologi Penelitian Ilmu Keperawatan. Salemba Medika. Jakarta. hal 13-31.

Sangadji, E. M. dan Sopiah. 2010. Metodologi Penelitian, Pendekatan Praktis dalam Penelitian. Andi. Yogyakarta. hal 1-100.

Steel, R. G. dan J. H. Torrie. 1989. Prinsip Prosedur Statistika (Terjemahan oleh Bambang Sumantri). Gramedia. Jakarta. hal 425-428.

Subyakto, S., D. Sutende., M. Afandi dan Sofiati. 2009. Budidaya Udang Vaname (Litopenaeus vannamei) Semi Intensif dengan Metode Sirkulasi Tertutup untuk Menghindari Serangan Virus. Jurnal Ilmiah Perikanan dan Kelautan, 1(2): 1-2.

Wellborn, T. L. and W. A. Rogers. 1966. A Key to The Common Parasitic Protozoans of North American Fishes. Agricultural Experiment Station. Auburn University. 18 p. 